\title{
Potential Benefits from 3D Printing and Dental Pulp Stem Cells in Cleft Palate Treatments: An In Vivo Model Study
}

\author{
Rosales Ibáñez Raúl*1, Cubo Mateo Nieves², Rodríguez Lorenzo Luis María ${ }^{3,4}$, Rodríguez Navarrete \\ Amairany ${ }^{1}$, Flores Sánchez María Leticia 0lga ${ }^{5}$ \\ ${ }^{1}$ Laboratorio de Ingeniería Tisular, Fes Iztacala, UNAM, México \\ ${ }^{2}$ ITEFI-CSIC, Madrid, Spain \\ ${ }^{3}$ ICTP-CSIC, Madrid, Spain \\ ${ }^{4}$ CIBER-BBN, Madrid, Spain \\ ${ }^{5}$ Bioterio de Fes-Iztacala, UNAM, México \\ *Corresponding author: Rosales Ibáñez Raúl, Laboratorio de Ingeniería Tisular, Fes Iztacala, UNAM, Mexico
}

\begin{abstract}
ARTICLE INFO
Received: 絊 March 13, 2019

Published: 蔧 March 22, 2019

Citation: Rosales Ibáñez R, Cubo Mateo $\mathrm{N}$, Rodríguez Lorenzo Luis $\mathrm{M}$, Rodríguez Navarrete A, Flores Sánchez María Leticia O. Potential Benefits from

ABSTRACT

Cleft palate is one of the most frequent anomalies in the head and neck region. Different treatments have been used but with each, there are still some disadvantages such as fistulas. The use of a 3D scaffold, with osteoinductive properties, from an easily accessible source, such as dental pulp stem cells, should improve and shorten the treatment of a cleft palate. We conducted a pilot study, in a Vietnamese pig, to evaluate the effectiveness of treating a critical defect of the palate bone, with a 3D Polycaprolactone (PCL) scaffold, in combination with a Beta Tricalcium Phosphate powder ( $\beta$-TCP) and Pig Dental Pulp Stem Cells (pig DPSC) obtained from the subject pig.
\end{abstract} 3D Printing and Dental Pulp Stem Cells in Cleft Palate Treatments: An In Vivo Model Study. Biomed J Sci \& Tech Res 16(2)-2019. BJSTR. MS.ID.002831.
Keywords: Dental Pulp Stem Cells; 3D Scaffold Cleft Palate Regeneration

\section{Introduction}

The interest in bone tissue engineering and regeneration therapies, have grown in parallel with the increase in bone fractures due to accidents, musculoskeletal disorders and congenital diseases such as cleft palates [1-3]. Cleft lips and/or palates are the most common congenital malformations of the head and neck and occur in the setting of multiple genetic and environmental factors [4]. In this sense, the repair of the cleft palate intends to establish the division between the oral and nasal cavity, thereby improving feeding, speech, and eustachian tube dysfunction, all while minimizing the negative impact on maxillary growth [5]. For example, although bone healing mediated by iliac crest has been very promising, its efficacy has not always been achieved. Perhaps this is due to the amount of implanted tissue or other factors but whatever the reason is, literature reports that after the treatment palatal wound dehiscence, a residual fistula has an estimated occurrence ranging from 3.4 to $27 \%$ [6] and other percentages $[7,8]$. With the advent of scaffolds printed in three dimensions (3D) [9], we can perhaps overcome those deficiencies. Scaffolds made by a 3D printer, having a microenvironment in three dimensions, may favor the comfort of cells, their survival and proliferation. In this paper the potential of pig dental pulp stem cell in combination with 3D scaffolds for becoming a choice for cleft palate defects treatments is examined in an in vivo model. 


\section{Materials and Methods}

\section{Scaffolds Manufacturing}

The Polycaprolactone (PCL) used in this project was directly provided as a $1.75 \pm 0,005 \mathrm{~mm}$ filament for standard 3D printers (3D4makers.com, Mw: $84500 \pm 1000,100 \%$ pure, Haarlem, Netherlands). For the fabrication of the scaffolds, a Hephestos 2 (Prusa i3 - BQ, Madrid, Spain) with a heated bed was used. The extruder was a double drive gear, with a noozle of $400 \mu \mathrm{m}$.

\section{In Vivo model}

A male Vietnamese pig subtype was approved by the ethical committee (CE/FESI/052017/1174) for the pilot study. Central and lateral lower incisors were extracted to isolate the stem cells. The pulp was cut into small pieces and treated with $0.05 \%$ collagenase (Sigma Aldrich, USA) and low glucose Dulbecco's modified Eagle Medium (DMEM) (Bio-west, México) and incubated at $37^{\circ} \mathrm{C}$ for 20 minutes. After the collagenase inactivation, the cell suspension was centrifuged at $350 \mathrm{~g}$ for $5 \mathrm{~min}$, the cell pellet was cultured with low glucose Dulbecco's modified Eagle Medium (DMEM) (Bio-west, México), supplemented with 10\% Fetal Calf Serum (FCS) (Bio-west, México) and $1 \%$ penicillin-streptomycin (Sigma Aldrich, USA), and incubated at $37^{\circ} \mathrm{C}$ in an atmosphere of $5 \% \mathrm{CO}_{2}$ until the cells reached $80 \%$ confluence. The culture media was changed every third day. The third passage was used for the following test and for the implantation in vivo.

\section{Immunophenotype of Pig Dental Pulp Stem Cells}

The pig dental pulp stem cells phenotype was analyzed by flow cytometry, utilizing the following antibodies, coupled to fluorophores CD90-FITC, CD105 VB421. Previously, harvested stem cells were seeded in 6 wells plates, when the cells reached $80 \%$ confluence were placed in $1.5 \mathrm{ml}$ eppendorf tubes, centrifuged at $600 \mathrm{~g}$. The cellular pellet was washed with phosphate buffer saline (PBS) supplemented with $2 \%$ of fetal calf serum and centrifuged again at $600 \mathrm{~g}$ for 5 minutes. The cells were then resuspended in a $400 \mu \mathrm{l}$ volume of PBS, supplemented with $2 \%$ FCS. before $0.3 \mu \mathrm{l}$ of the two coupled antibodies were added without dilutions and then incubated for $15 \mathrm{~min}$ at room temperature before being read using the CytoFLEX LX flow cytometer (BRVYNI), selecting the corresponding filters for the detection of each of the fluorochromes with 10,000 events being captured for each sample. Pig dental pulp cells, without coupled antibodies, were used as controls.

\section{Scaffold Sterilization and Seed of the Pig Dental Pulp Stem Cells}

The 3D scaffold (Figure 1) was sterilized with ethanol at $70 \%$, and then left in a physiological solution with antibiotic and antifungal properties for 24 hours. After this time it was placed in UV radiation for an additional $24 \mathrm{hrs}$, before the pig's dental pulp stem cells were planted in layers. First a layer, with 300 thousand cells, was placed in the scaffold, then a layer of Beta Tricalcium Phosphate powder ( $\beta$-TCP) (R.T.R granules, Septodont, France) was added, thus 5 layers of each component were applied. The construct (3D scaffold + pig DPSC $+\beta$-TCP) was incubated for 48 hrs, before the surgery. The pig was anesthetized and a defect of $10 \mathrm{~mm}$ was created in the left side of the maxilla (Figure 2), the construct was placed in the defect (Figure 3 ) and sutured with vicryl three zeros. After 6 months the pig was euthanized and the maxilla was removed. An occlusal X-ray was taken before the maxilla was subsequently placed in $4 \%$ formalin for histological analysis.

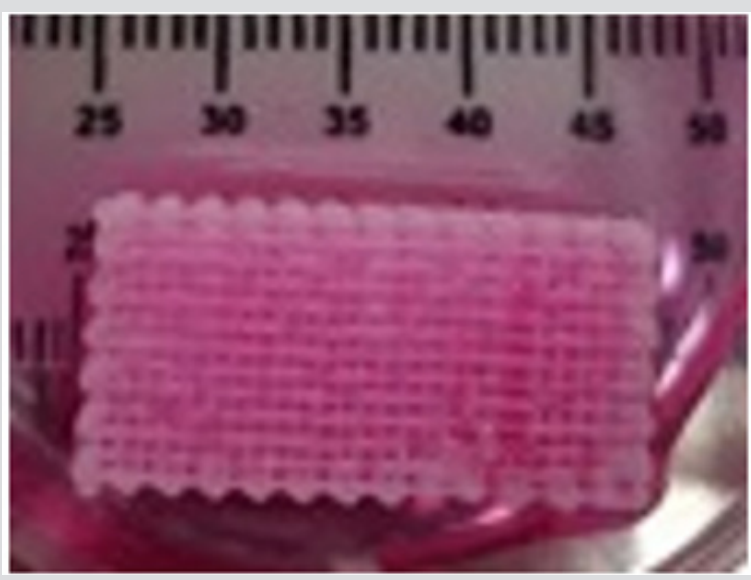

Figure 1:3D polycaprolactone scaffold.

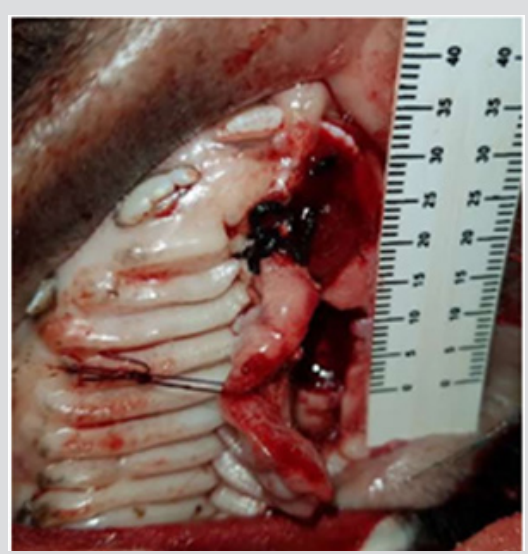

Figure 2: A defect of $10 \mathrm{~mm}$ was created in the left side of a male Vietnamese pig maxilla.

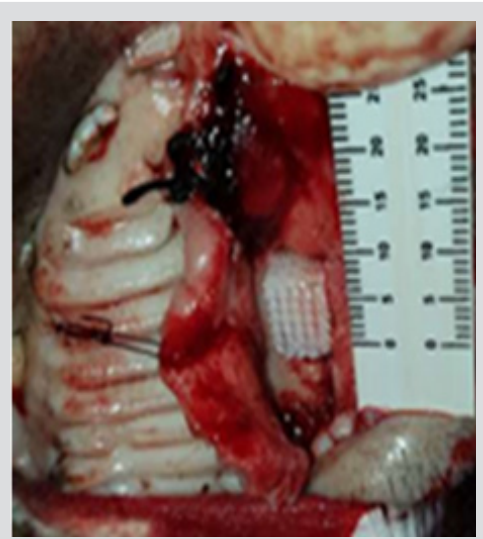

Figure 3: The construct (3D scaffold + pig DPSC $+\beta-T C P)$ was placed in the defect of a male Vietnamese pig maxilla. 


\section{Results}

It was possible to cultivate the pig's dental pulp stem cells by means of enzymatic digestion. The first cells proliferated were between days 2 through 4 , which showed elongated fibroblast-like cells (Figure 4). Cultures reached $80-90 \%$ confluence around day 14. The phenotype pig dental pulp stem cell were $91.0 \%$ positive for antibody CD 90 and 80.0\% to antibody CD 105 (Figure 5) Animal welfare was supervised by the University's veterinarians. The pig was fed a soft diet for the first week so there would be no problems chewing. There were no signs of infection after the surgery not through the experiment's end point at 6 months, when euthanasia was practiced in accordance to the principles of minimal pain and/ or distress to the pig. Radiographically, we can see that almost entire defect closed in the yellow circle (Figure 6). This regeneration could be confirmed with computed tomography and histological analysis.

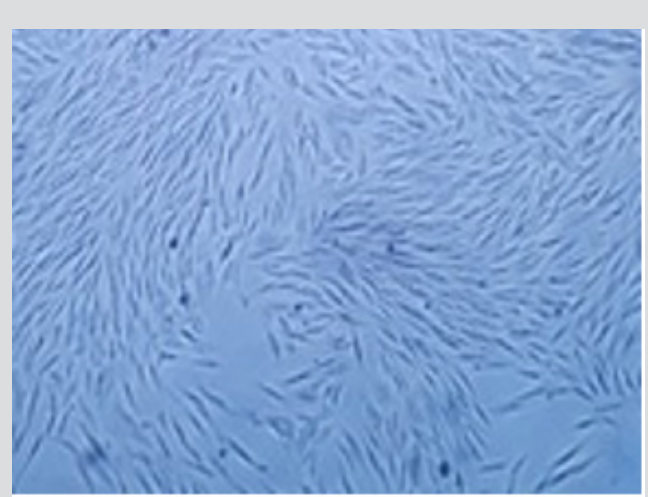

Figure 4: Morphology of pig DPSC isolated by means of enzymatic digestion, mainly displayed elongated fibroblast-like cells, $4 \mathrm{x}$ by optical microscope.

\section{Conclusion}

Stem cells from dental pulp are easy to obtain while also having the capacity to proliferate quickly. The use of 3D scaffolds, with osteo-receptor properties, helps to induce the regeneration of good quality bone in both the short and medium term.

\section{Grant}

Research and Technological Innovation Project Support Program, PAPIIT, IA209417, UNAM.

\section{References}

1. Flores Cedillo ML, Alvarado Estrada KN, Pozos Guillén AJ, Murguía Ibarra JS, Vidal MA, et al. (2016) Multiwall carbon nanotubes/polycaprolactone scaffolds seeded with human dental pulp stem cells for bone tissue regeneration. J Mater Sci Mater Med 27(2): 33.

2. Martin Del Campo M, Rosales Ibañez R, Alvarado K, Sampedro JG, Garcia Sepulveda CA, et al. (2016) Strontium folate loaded biohybrid scaffolds seeded with dental pulp stem cells induce in vivo bone regeneration in critical sized defects. Biomater Sci 4(11): 1596-1604.

3. Rodríguez Méndez I, Mar Fernández Gutiérrez M, Rodríguez Navarrete A, Rosales Ibáñez R, Benito Garzón L, et al. (2018) Bioactive Sr(II)/
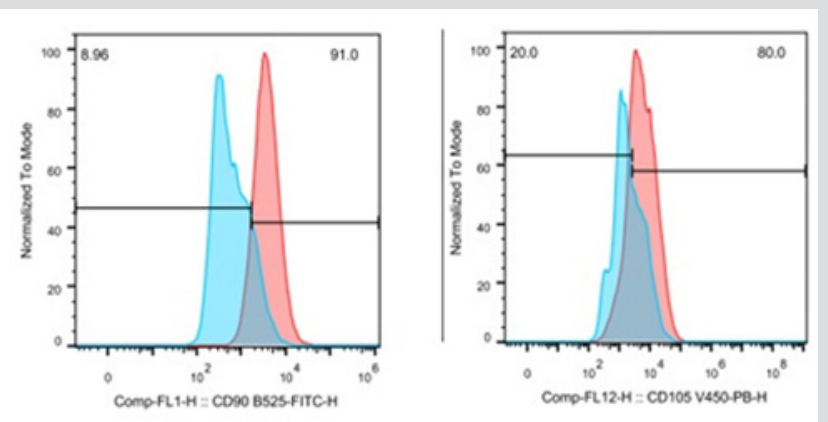

Figure 5: Phenotype pig dental pulp stem cell were $91.0 \%$ positive for antibody CD 90 and $80.0 \%$ to antibody CD 105 respectively, using the CytoFLEX LX flow cytometer (BRVYNI).

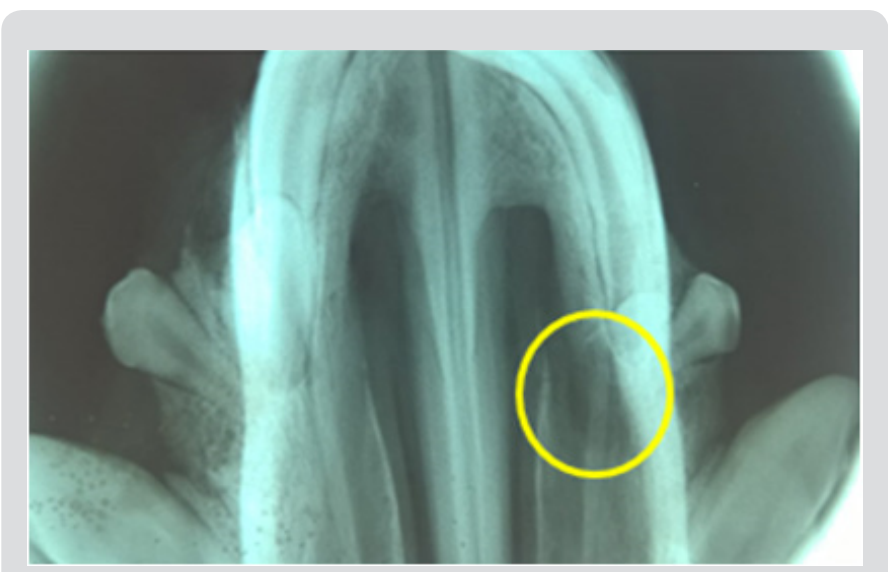

Figure 6: Radiographically, see that almost entire defect closed in the yellow circle.

Chitosan/Poly("-caprolactone) scaffolds for craniofacial tissue regeneration: In Vitro and In Vivo behavior. Polymers 10(3): 279.

4. Genisca AE, Frías JL, Broussard CS, Honein MA, Lammer EJ, et al. (2009) Orofacial clefts in the national birth defects prevention study, 19972004. Am J Med Genet A 149A(6): 1149-1158.

5. Dao AM, Goudy SL (2016) Cleft palate repair, gingiva periosteoplasty, and alveolar bone grafting. Facial Plast Surg Clin North Am 24(4): 467476.

6. Nicol BR, Naung NY, Van Sickels JE (2019) Simple technique to repair a residual oronasal fistula in bilateral cleft lip and palate patients. J Oral Maxillofac Surg S0278-2391(19): 3012-3014.

7. Lu Y, Shi B, Zheng Q, Hu Q Wang Z (2010) Incidence of palatal fistula after palatoplasty with levator veli palatini retropositioning according to Sommerlad. Br J Oral Maxillofac Surg 48(8): 637-640.

8. Hardwicke JT, Landini G, Richard BM (2014) Fistula incidence after primary cleft palate repair: A systematic review of the literature. Plast Reconstr Surg 134(4): 618e-627e.

9. Bauermeister AJ, Zuriarrain A, Newman MI (2016) Three-dimensional printing in plastic and reconstructive surgery: A systematic review. Ann Plast Surg 77(5): 569-576. 


\section{ISSN: 2574-1241}

DOI: 10.26717/BJSTR.2019.16.002831

Rosales Ibáñez Raúl. Biomed J Sci \& Tech Res

(c) (i) This work is licensed under Creative

Submission Link: https://biomedres.us/submit-manuscript.php

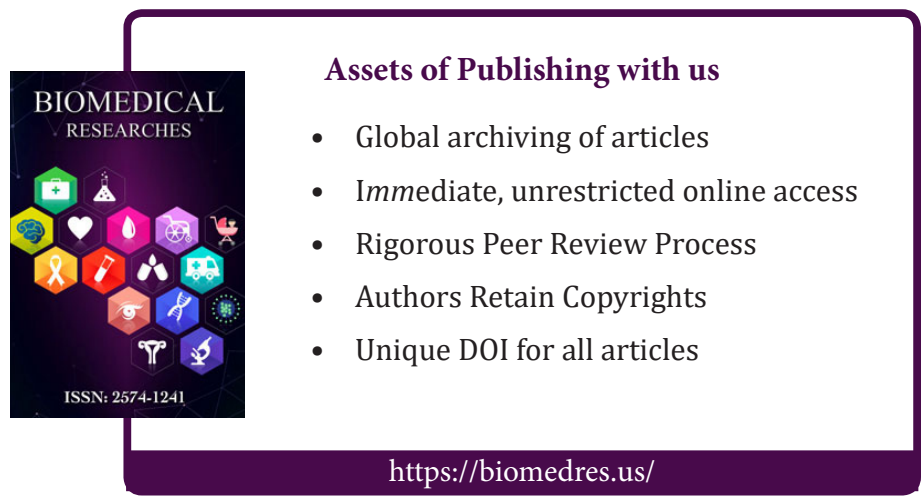

